\title{
Mudflat biota since the 1930s: change beyond return?
}

\author{
Karsten Reise • Elisabeth Herre • Manfred Sturm
}

Received: 15 June 2007 / Revised: 5 October 2007 / Accepted: 5 October 2007 / Published online: 16 November 2007

(C) Springer-Verlag and AWI 2007

\begin{abstract}
Where, since the 1980s, patchy and variable green algal mats are prevailing, distinct belts of an amphipod (Corophium volutator) and seagrass (Zostera spp.) had dominated in the 1930s. The zonation between tide marks has been mapped in a sheltered sedimentary bay in the Wadden Sea near the island of Sylt (coastal eastern North Sea). Maps on vegetation from 1924 and on selected macrobenthos from 1932 and 1934 are compared with biannual surveys conducted from 1988 to 2006. Rising high water levels and eutrophication are suggested to be major causes of the observed long-term changes. In front of a saltmarsh, a sandy beach developed and partly displaced former cyanobacterial mats. Advancing sandiness may have inhibited C. volutator and facilitated lugworms, Arenicola marina, in the upper tidal zone. A variable occurrence of green algal mats arising in the 1980s affected infauna and seagrass by smothering the biota underneath. This dissolved a coherent belt of Zostera noltii. In the lower tidal zone, natural disturbances had lasting effects on the occurrence of mussels with attached fucoid algae. The spectrum of species became enriched by alien species (13\% of macrobenthic taxa). A reversal to habitat structure and biotic zonation of the 1920-1930s does not seem possible. Aliens, in combination with climate change, are expected to further divert the ecological pattern to new configurations.
\end{abstract}

Communicated by J. van Beusekom.

K. Reise $(\bowtie) \cdot$ E. Herre $\cdot$ M. Sturm

Alfred Wegener Institute for Polar and Marine Research,

Wadden Sea Station Sylt, 25992 List, Germany

e-mail: karsten.reise@awi.de
Keywords Alien species - Arenicola Corophium . Eutrophication · Green algae · Intertidal · Sea level rise · Wadden Sea $\cdot$ Zostera

\section{Introduction}

At coasts, long-term ecological change is normal. Between decades, we would expect changes caused by intrinsic succession and by responses to extrinsic trends and events, including human impacts. Comparisons between time intervals several decades apart have often revealed striking changes in the marine benthos in the course of the twentieth century (e.g., Kröncke 1992; Pearson et al. 1985; Rasmussen 1973; Reise et al. 1989; Rosenberg et al. 1987), and combinations of various time series data suggest that ecological regime shifts may be a general phenomenon in regional seas (Hare and Mantua 2000; Nes et al. 2007; Weijerman et al. 2005). The aim of this study is to elucidate the magnitude of change over a time span of seven decades, and to judge whether there is a chance of reversal. This is currently an issue because ecological quality is often evaluated in comparison with historical references (Ten Brink et al. 1991; European Water Framework and Habitat Directives).

Ecological research, leeside of the barrier island of Sylt, at the eastern North Sea coast commenced more than a century ago (Reise et al. 1989). Königshafen, an intertidal bay at the northern tip of the island, was mapped and described with respect to macrobenthos in the 1920-1930s (Nienburg 1927; Wohlenberg 1937). Wohlenberg noticed in the inner part of the bay, distinct biotic belts between tidemarks in 1932. Two years later he noticed some change and repeated his survey (Fig. 1). We revisited that site in 1988 and then continued surveys every other year until 2006 to see 

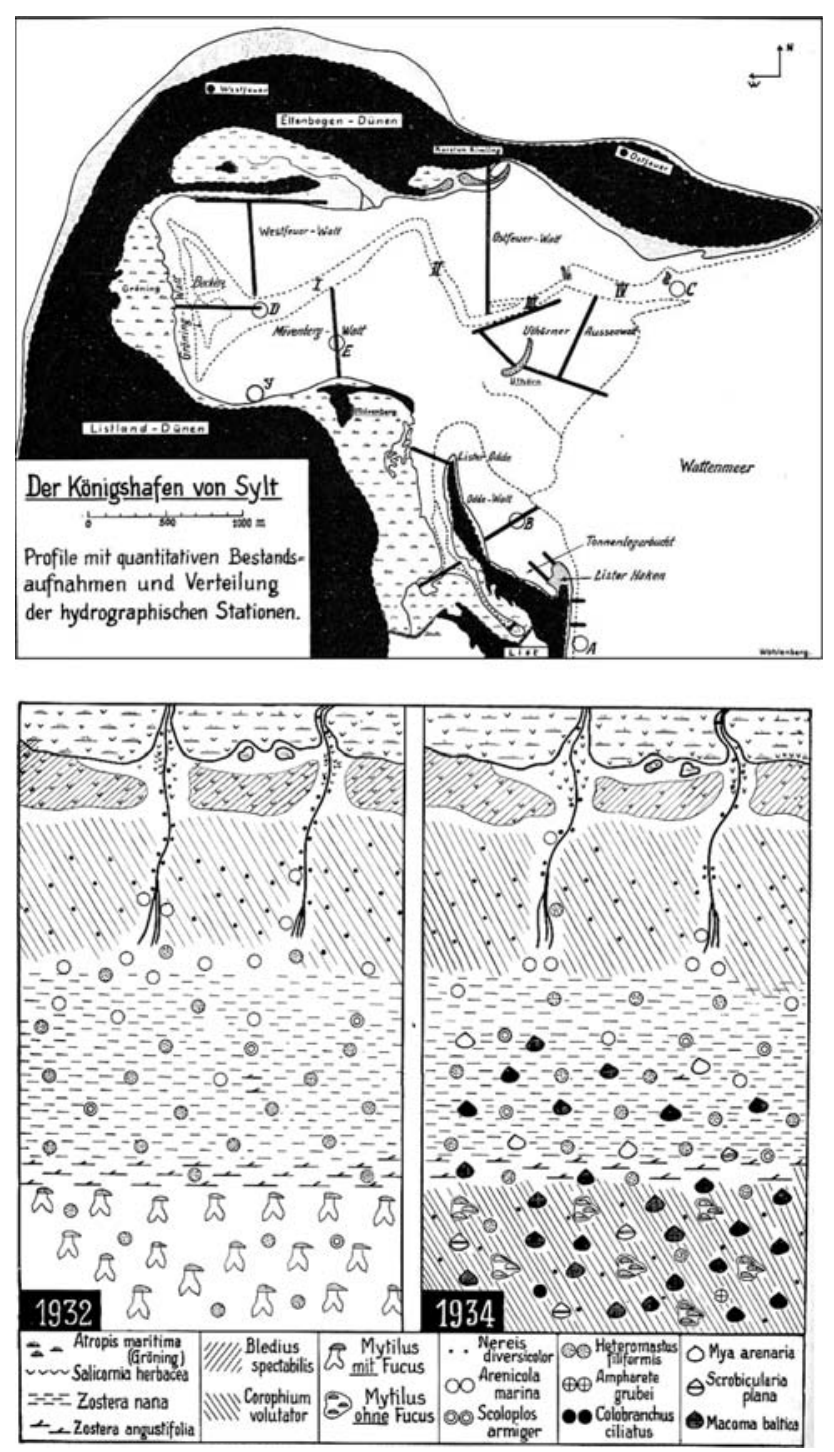

Fig. 1 Königshafen (Wohlenberg 1937: Abb. 1) at the island of Sylt in the northern Wadden Sea (above): dunes in black, saltmarsh is stippled, low tide line is dotted; bars mark intertidal transects, and the left half of transect $D$ in western Königshafen corresponds to the position of the mapped area of $150 \times 250 \mathrm{~m}$ (below). Stippled: saltmarsh with Puccinellia (Atropis) maritima, two creeks are indicated leaving the marsh; transverse hatching: mats of cyanobacteria with castings of the staphilinid beetle Bledius spectabilis; transverse hatching in opposite direction with dots: belt with mudshrimp Corophium volutator and ragworm Nereis diversicolor; thin and bold horizontal dashes: Zostera noltii (nana) and Z. marina (angustifolia), respectively; hatched caps: mussels Mytilus edulis with or without wrack Fucus vesiculosus forma mytili. Other symbols refer to polychaetes or clams (spat)

whether survey results two years apart are more similar than those after decades have elapsed.

The chosen site is ideal for such a decadal comparison because there were no direct human alterations of habitat structure, a condition that is rather rare for sheltered shores in the Wadden Sea (Reise 2005) or in Europe (Airoldi and Beck 2007). Besides succession and extreme events such as severe winters or storm surges, causes of change in the Wadden Sea over the last decades have been attributed to eutrophication (van Beusekom 2005), fall and rise of apex predators (Lotze 2005), alien invaders (Reise et al. 1999), and climate change (Diederich et al. 2005; Loebl et al. 2006; Nehls et al. 2006). An attempt is made to relate the observed changes to these processes as well as to sea level rise.

\section{Area and methods}

Dunes on Sylt provide shelter against storm surges to a bay of about $6 \mathrm{~km}^{2}$, named "Königshafen" after a Danish king who battled there in 1644 . Saltmarshes comprise $11 \%$, bare high sands and beaches $7 \%$, intertidal sand and mud flats $78 \%$, and a meandering channel $4 \%$, of the bay area. Tidal range is $1.8 \mathrm{~m}$, salinity close to $30 \mathrm{psu}$, and mean annual water temperature about $9^{\circ} \mathrm{C}$ (Reise et al. 1994).

The nearby Wadden Sea Station Sylt founded in 1924 and a diversity of intertidal habitats prompted scientists to study geological and ecological aspects of Königshafen since that time. Nienburg (1927) described and mapped seagrasses and macroalgae, which was later supplemented and updated by Kornmann (1952) and Schories et al. (1997). Kolumbe (1932) described the morphodynamics, continued by Bayerl and Higelke (1994). Sediment types were mapped by Wohlenberg (1937) and analyzed in detail by Austen (1992). Wohlenberg (1937) described and mapped macrobenthos in relation to habitat characteristics, which was later supplemented and updated by Reise (1985) and Reise et al. (1994) among others.

The study site was chosen by Wohlenberg (1937) because of its relatively steep slope from a saltmarsh $1.5 \mathrm{~m}$ downward to a muddy depression over a distance of $250 \mathrm{~m}$ (isolines in a topographic map from 1991; Amt für Landund Wasserwirtschaft Husum, Germany). This is equivalent to an inclination of $5 \mathrm{~mm}$ per $\mathrm{m}$ perpendicular to the shore. The macrobenthos exhibited a conspicuous zonation. The exact location of this area, shown in Fig. 1, was not given by Wohlenberg. However, from the indicated saltmarsh creeks and the given position of his "transect D" (Wohlenberg 1937: Abb.1) it is possible to infer size and position of the rectangular study area to approximately $150 \times 250 \mathrm{~m}$ and the coordinates are $55^{\circ} 02^{\prime}, 325 \mathrm{~N}$ and $55^{\circ} 02^{\prime}, 407 \mathrm{~N}$, and $8^{\circ} 23^{\prime}, 802 \mathrm{E}$ and $8^{\circ} 24^{\prime}, 036 \mathrm{E}$. Habitat structures are fairly homogeneous in the longshore direction.

Wohlenberg (1937) does not explicitly describe his method of macrobenthic assessment. Apparently, he sampled along a transect in October 1932 and July 1934 with a corer of $500 \mathrm{~cm}^{2}$ in cross-section and sieved with a $1-\mathrm{mm}$ mesh to retain macrofauna. However, results are not 
Fig. 2 Occurrence of ragworms Nereis diversicolor (small dots) and $N$. virens (large filled circle) between tide marks from 1988 to 2006 (Gröning-Watt,

Königshafen Sylt)
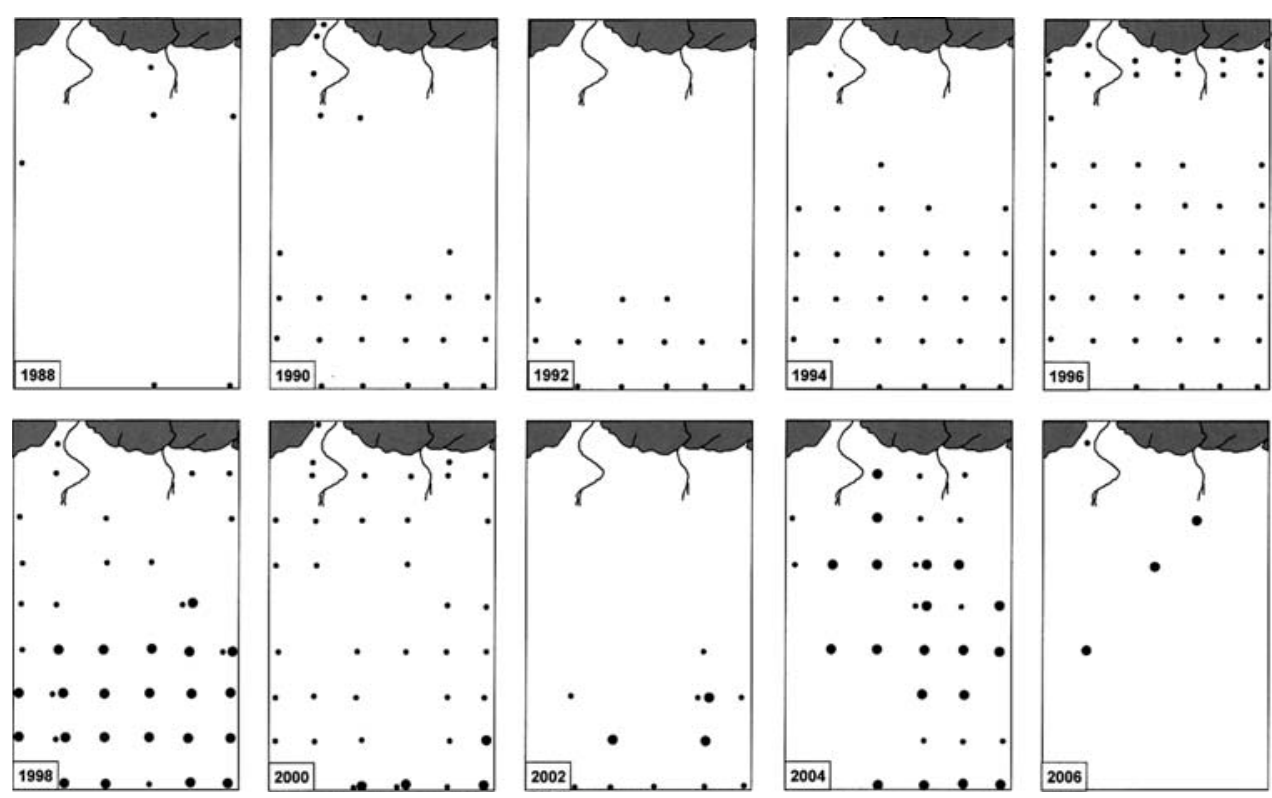

presented in a data matrix, and we thus cannot conduct a statistical comparison between his and our data. Wohlenberg only refers to selected abundance data in his text, and the taxa presented in Fig. 1 do not seem to comprise all of those encountered. For example, he does not record the presence of the gastropods Hydrobia ulvae and Littorina littorea, although in his list of species for Königshafen, the former is mentioned to occur everywhere in the upper intertidal together with Corophium volutator and Zostera noltii, and the latter to be associated with seagrass meadows in particular.

When revisiting Wohlenberg's study site, we adopted a sampling design capable to generate a map of macrobenthic zonation comparable to the one shown in Fig. 1. In the longshore direction, we recorded macrobenthos at intervals of $30 \mathrm{~m}$. Perpendicular to the shore, records were first taken every $10 \mathrm{~m}$ across the upper $40 \mathrm{~m}$ to account for the narrow stripes of transitional habitats between saltmarsh and tidal flat. Then, every $30 \mathrm{~m}$ from 40 to $250 \mathrm{~m}$ records were taken. Altogether this amounted to a grid of 72 sampling stations within the rectangular site. Symbols in Figs. 2-4, 6, 7 are given for these stations and contour lines are interpolated.

At each station, all taxa of plants, invertebrates and small fish visible on the sediment surface were recorded per $\mathrm{m}^{2}$. In the presence of seagrass and algae, areas of $10 \mathrm{~m}^{2}$ were chosen to estimate coverage in percent. For invertebrates depositing burrow material or feces on the
Fig. 3 Occurrence of lugworms Arenicola marina juveniles (small dots, fecal strings of $<2 \mathrm{~mm}$ in $\emptyset$ ) and adults (large filled circle, fecal strings $\geq 2 \mathrm{~mm}$ in $\emptyset$ ) between tide marks from 1988 to 2006 (Gröning-Watt, Königshafen Sylt)
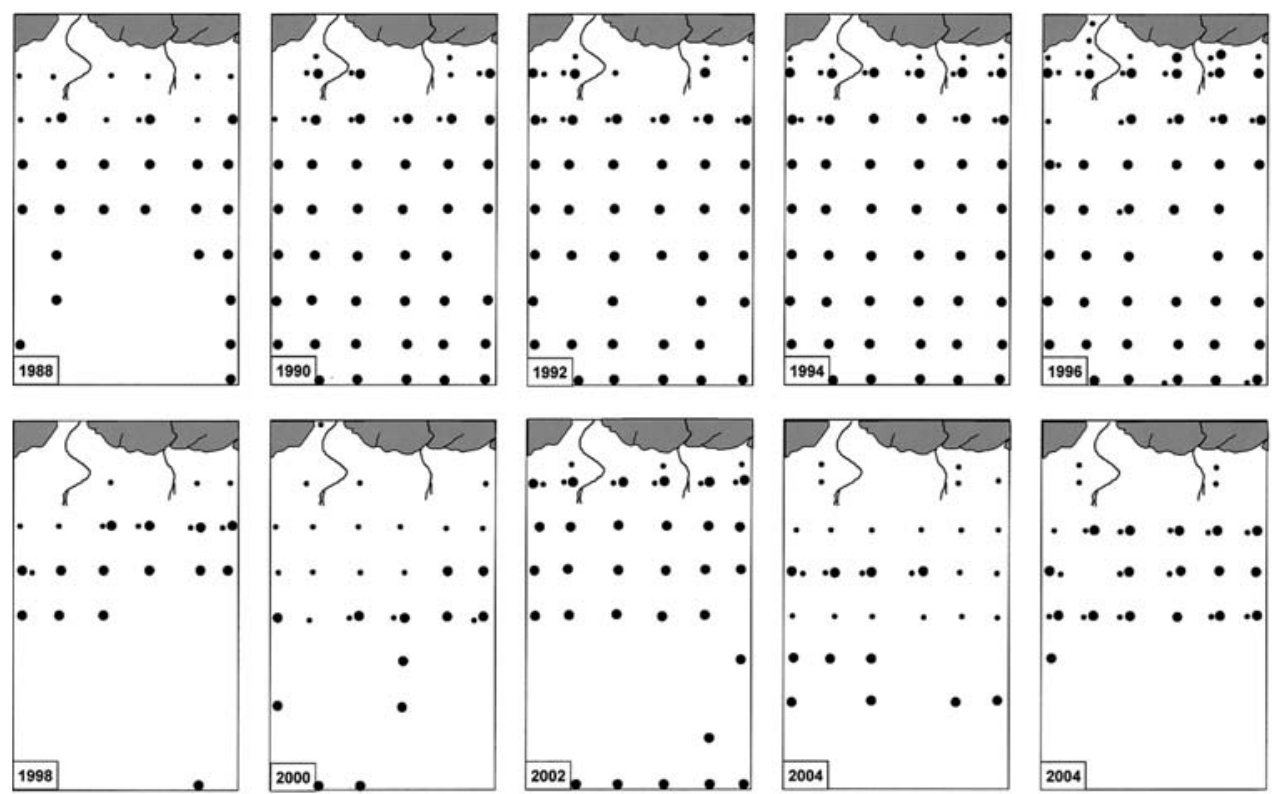
surface in a species-characteristic form (e.g., Bledius spectabilis, Heteromastus filiformis, Arenicola marina with fecal strings of $<2$ and $\geq 2 \mathrm{~mm}$ in diameter $(\varnothing)$ for juveniles and adults, respectively) or having protruding tubes (e.g., Lanice conchilega, spionid polychaetes), these structures were taken as evidence of occurrence. This method failed where green algal mats completely covered the sediment. After having inspected the surface, sediment of approximately $0.1 \mathrm{~m}^{2}$ was excavated to a depth of about $0.3 \mathrm{~m}$ and all visible fauna was identified and recorded. When necessary, doubtful specimens were identified under a stereomicroscope in the lab. Maps in Figs. 2, 3, 6, 7 depict the presence/absence of respective species at sample positions.

\section{Physical change}

Relevant trends in physical factors were not measured in this study but are reviewed here from the literature. The geomorphological configuration has apparently changed little over the last two centuries (Kolumbe 1932; Newig 1980; Bayerl and Higelke 1994). The saltmarsh, of which the seaward edge is shown in Fig. 1, was already mapped around 1870 (Meyn 1876). Aerial photographs from 1936 until today (Bayerl and Higelke 1994; T. Dolch personal communication) show an almost unchanged seaward extension. Also a tidal channel meandering into Königshafen did not significantly shift its bed over the last 7 decades. This suggests, geomorphologically, a rather stable environmental setting over that period.

Sediments of the bay originate from migrant dunes that moved from an exposed beach with relatively coarse sand into the bay from a southwestern direction (Wohlenberg 1937; Priesmeier 1970). From eastern direction, floodwaters entered the bay and deposited fine-grained sediments. Because of these two sources, this highly sheltered bay is sandy with some interspersed mud flats. The latter decreased in area and the remaining mud became more compact since the 1930s (Austen 1994). This suggests a limited supply of fine sediments (Pejrup et al. 1997).

For the study site selected by Wohlenberg (1937), he described the upper 100-m zone as composed of water-saturated muddy sand or sandy mud, and the lower zone as semi-fluid mud, oversaturated with water down to $15 \mathrm{~cm}$, partially even deeper and impossible to walk across then. Today, the upper zone is firm sand and the lower part is sandy mud and mud with a semi-fluid layer $<15 \mathrm{~cm}$ deep. In winter, a thin muddy layer moves onshore and then retreats again towards summer. Analyzing topographies between 1950 and 1993 in this tidal area, Higelke (1998, Abb. 11) indicates erosion at the upper and deposition in the lower zone.
This may have been caused by rising water levels with a concomitant increase in hydrodynamics. Mean tidal range of $1.8 \mathrm{~m}$ (in 2006) at the nearby tide gauge at List harbor has increased $3.5 \mathrm{~mm}$ annum $^{-1}$ with $+2.1 \mathrm{~mm}$ for mean high and $-1.4 \mathrm{~mm}$ for mean low tide level (1952-1987; Jensen et al. 1992). To the rise in mean high tide level, the 90-percentile of winter storm surge increase of $4.1 \mathrm{~mm} \mathrm{a}^{-1}$ (1958-2002; Weisse and Plüß 2006) should be added when considering the frequency of submergence for the saltmarsh. For the last 5 or 7 decades, these trends imply an increase of 31 or $43 \mathrm{~cm}$ in storm surge levels, respectively.

\section{Results}

From the saltmarsh edge down to low tide level, 67 taxa of macrobenthos have been recorded over the years. Of these 8 are phanerogams, 13 macroalgae, 15 annelids, 13 molluscs, 7 crustaceans, and 11 belong to various other groups. Nine species (13\%) are known or suspected to be of exotic origin: Spartina anglica, Sargassum muticum, Gracilaria vermiculophylla, Nereis virens, Crepidula fornicata, Crassostrea gigas, Ensis americanus, Elminius modestus, and Molgula manhattensis (Reise et al. 1999; Wolff 2005). None of these aliens were present in the 1930s in Königshafen. A tussock $(\sim 10 \mathrm{~m}$ in $\emptyset$ in 2006$)$ of the cordgrass, S. anglica, first noted in 1996, is rapidly expanding at a saltmarsh creek near the boundary of the study site.

Number of taxa between the 1930s and later years are not comparable because Wohlenberg (1937) apparently does not mention all taxa he encountered. Of those he mentioned, only the amphipod Corophium volutator was consistently absent in the years since 1988. There is no indication that the composition of the saltmarsh vegetation at the seaward edge has changed since the descriptions provided by Nienburg (1927) and Wohlenberg (1937). Vegetation was and is short-grazed by sheep. Dominant is Puccinellia maritima and associated are Salicornia spp., Suaeda maritima and Spergularia salina. All are characteristic for the lower saltmarsh zone inundated by $\geq 100$ tidal floodings per year. This lack of change implies that the saltmarsh kept growing upwards by sediment accretion in concert with rising flood levels.

Comparisons of aerial photographs from 1936 and 2006 do not suggest a significant change in the position of the saltmarsh edge (T. Dolch, personal communication). However, the edge is fringed by a sandy berm or beach $5-15 \mathrm{~m}$ wide, which is not mentioned in Wohlenberg (1937). Instead, he mapped mats of cyanobacteria in front of the saltmarsh, in summer marked by numerous mounds created by a staphilinid beetle Bledius spectabilis which grazes on the mats (Fig. 1). Both still occur in small patches but otherwise have given way to the sandy berm. 
Fig. 4 Green algal mats ( $\geq 50 \%$ coverage, shaded) between tide marks from 1988 to 2006 (Gröning-Watt, Königshafen Sylt)
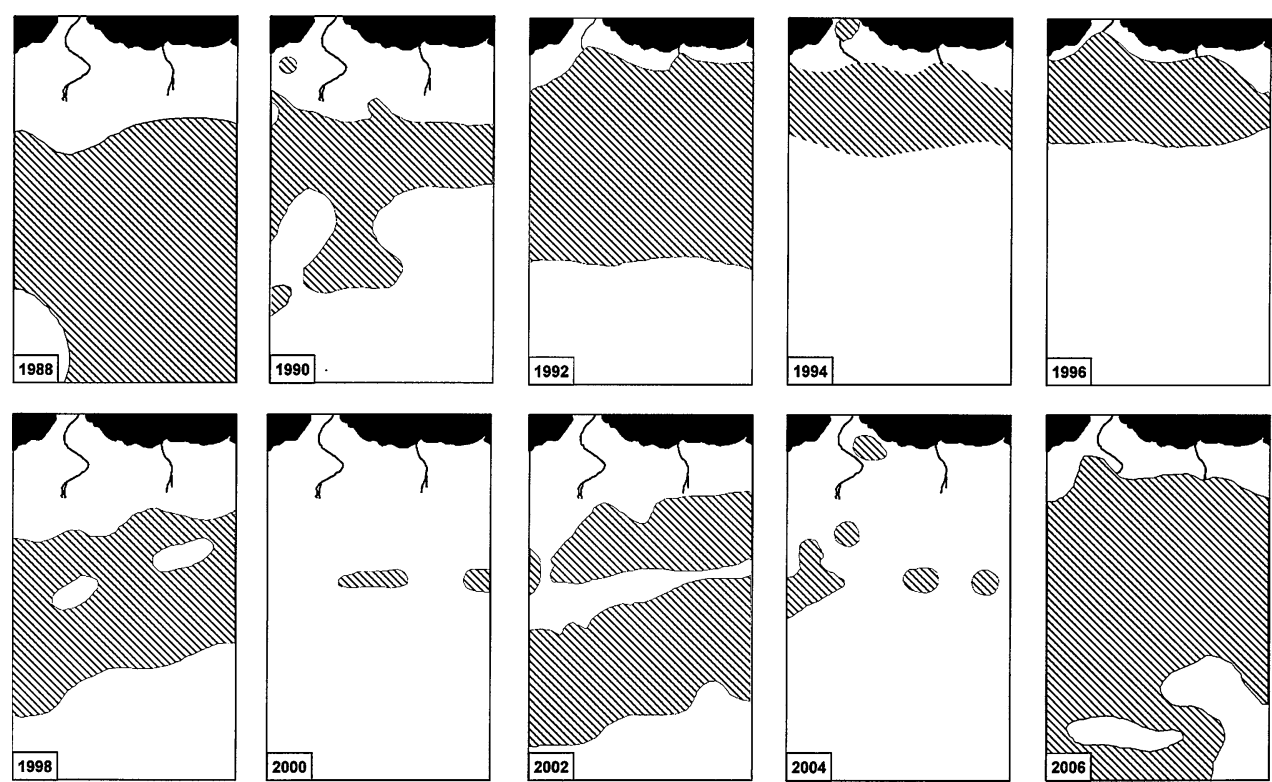
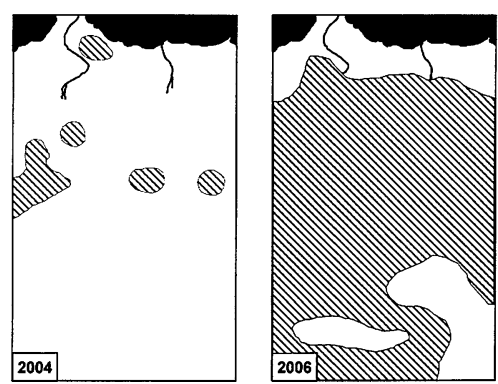

In the next zone Wohlenberg (1937) recorded a $50 \mathrm{~m}$ wide belt populated by $C$. volutator with $2,580 \mathrm{~m}^{-2}$ in October 1932 and $11,520 \mathrm{~m}^{-2}$ in July 1934 while none at all have been found in the recent period of observation. C. volutator also invaded the low tidal zone in 1934 with $2,160 \mathrm{~m}^{-2}$ after the fucoid algal cover had died back (Fig. 1). Always associated with C. volutator was Nereis diversicolor. This ragworm population varied strongly in distribution and frequency from 1988 onwards and cannot be ascribed to any particular zone although there was a tendency to concentrate at upper and lower shore with a lower frequency at mid shore level (Fig. 2). From 1998 onwards, the larger congeneric $N$. virens moved in at the lower shore. In the 1930s, the lugworm population occupied a narrow range at the transition between Corophum-and Zostera-belt (Fig. 1). In the later period, Arenicola marina has extended its range, juveniles particularly in dense patches at the upper shore, and adults mainly at mid to low shore (Fig. 3).

From all changes since the 1930s, the most conspicuous is the advent of green algal mats (Fig. 4). Although variable from year to year, in most summers, thick mats of green algae covered large parts of the tidal zone $(37 \pm 25 \%$ of area with a cover of $\geq 50 \%$ ). Anoxic conditions were arising underneath, causing an exodus (e.g., A. marina) or mass mortality (e.g., Cerastoderma edule) in the fauna, and also the seagrass was turning whitish and then dying back. In addition to the thick mats, scattered patches of green algae occurred almost everywhere. In most years, these algal mats gradually appeared in June and culminated in JulyAugust and then gradually decayed or were washed away by storm surges in September and October (Fig. 5). At the study site, Enteromorpha spp. always dominated in the upper zone and was supplemented by patches of Chaetomorpha sutoria and Ulva spp. in the lower zone. Although compact during low tide exposure, mats are lifted during submergence and their position often shifted somewhat up and down in the tidal zone. Thus maps in Fig. 4 depict snapshots liable to change within days or weeks.

Wohlenberg (1937) merely mentions taxa of green algae in his commented list of species for Königshafen. Apparently
Fig. 5 Phytomass (g dry organic matter $\mathrm{m}^{-2}$ ) of green algal genera measured monthly from May to October on an area of 2,500 $\mathrm{m}^{2}$ at mid tide level from 1991 to 2006 (Gröning-Watt, Königshafen Sylt)

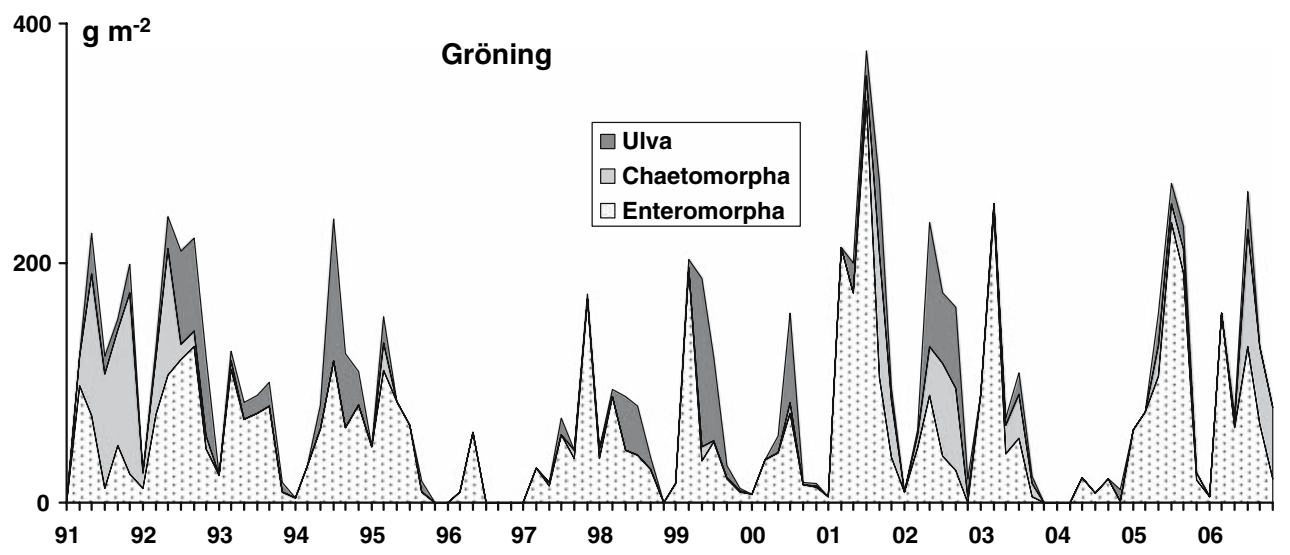


Fig. 6 Scattered and dense ( $\geq 25 \%$ coverage, shaded) Zostera marina (large filled circle) and $Z$. noltii (small dots) between tide marks from 1990 to 2006 (Gröning-Watt, Königshafen Sylt)
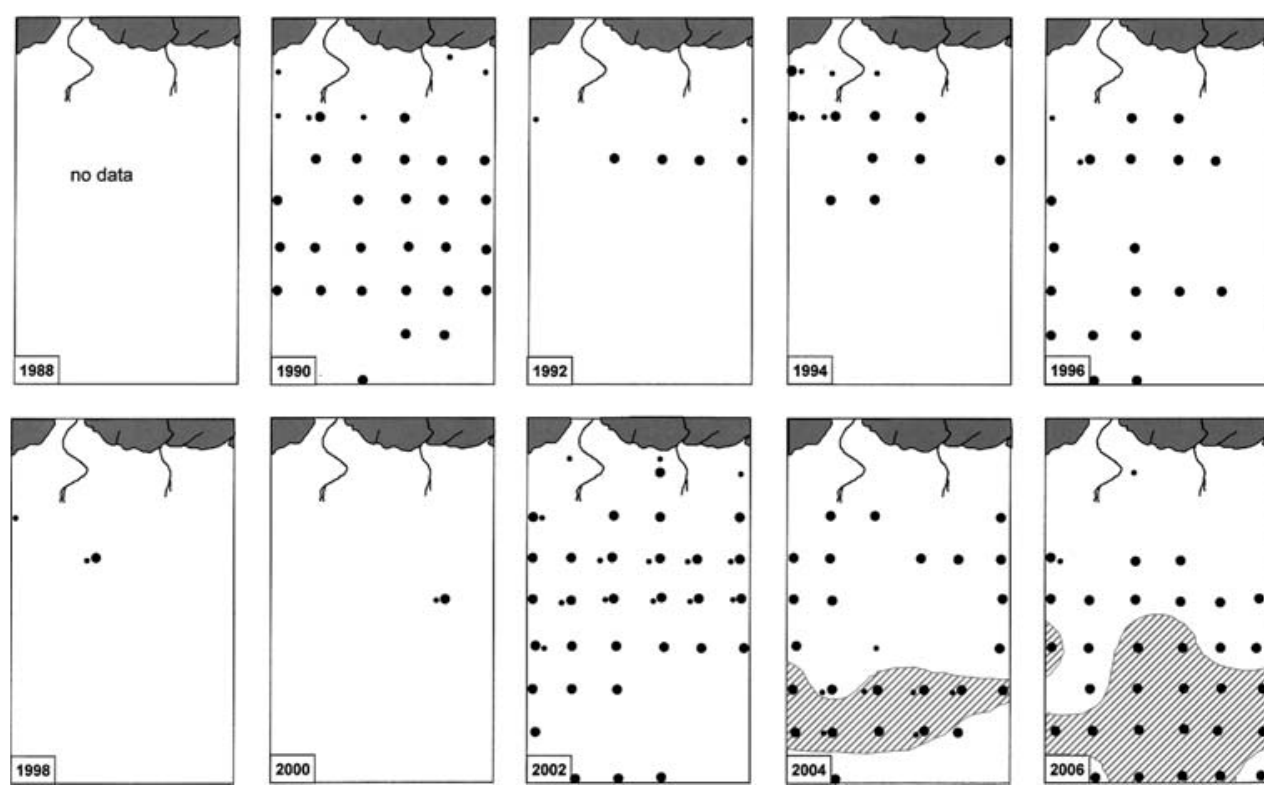

they were not conspicuous in the 1930s, and this agrees with Kornmann (1952) who identified various taxa attached to shells, pebbles and groins but does not mention any green algal mats on tidal sediments. However, Nienburg (1927) describes "green flats" in the uppermost tidal zone as an ephemeral phenomenon in spring and early summer composed of Enteromorpha clathrata, E. crinita, E. ramul$o s a$, and Rhizoclonium riparium. His vegetation map from 1924 indicates such a spring-bloom ("Wattblühen") for the Gröning-Watt close to the study site. In contrast, the thick algal mats encountered in the recent period are mainly composed of E. flexuosa, E. prolifera, and E. radiata (Schories et al. 1997) and are of a much wider distribution (Reise et al. 1989).

A continuous belt of Zostera noltii in Gröning-Watt was mapped in 1924, and Z. marina was encountered in the lower tidal zone mixed with Fucus vesiculosus forma mytili (Nienburg 1927). In the 1930s, only Z. noltii maintained its belt while $Z$. marina receded to a narrow fringe. Possibly the latter had been, at that time, affected by an upcoming so-called wasting disease, reported on in detail for the eastern Königshafen by Wohlenberg (1935). Seagrass was rather variable and patchy from 1990 to 2006 (Fig. 6). The mostly perennial $Z$. noltii became exceedingly rare while $Z$. marina, mostly with annual plants, attained in some years (particularly in 2004 and 2006), an even wider distribution than indicated for the 1930s in Fig. 1.

Mussels with attached wrack was a dominant feature in the lowest zone mapped in 1932 covering almost the entire sediment (Wohlenberg 1937) and this was also the case in 1924 (Nienburg 1927). However, Nienburg also reports that a storm in October 1926 has shifted the wrack upshore where it decayed the next year. Similarly, Wohlenberg (1937) noted a decay of $F$. vesiculosus forma mytili until it was almost absent in 1934. In the recent period, mussel beds with fucoid cover in the lower tidal zone were a dominant feature in 1990, 1992, and 1994 (Fig. 7). A severe winter in 1995/1996 with floes of ice moving to and fro removed this epibenthic structure and only, scattered clumps of mussels and wrack were found since then.

In 1934, Wohlenberg (1937) recorded spat of several clams not noticed 2 years earlier (Fig. 1). In the recent period, Macoma balthica, Mya arenaria and Cerastoderma edule were present in all years. The latter was particularly common, while Wohlenberg (1937) recorded these cockles only from the outer part of Königshafen in the 1930s. Scrobicularia plana, Abra alba, Ensis americanus, and Crassostrea gigas were present only in some years. The latter two are invaders that were not yet present in the region in the 1930s. Of the more frequent polychaetes, Wohlenberg (1937) found Scoloplos armiger in the seagrass belt and also, Heteromastus filiformis, in the muddy zone below (Fig. 1). In spite of strong variability between years, this pattern persisted into the recent period but $S$. armiger is now also found in the zone of the former Corophium-belt.

\section{Discussion}

Although the study site remained free of any direct physical human interference, 7 decades have altered the biota considerably. Almost three times as many taxa were recorded in the period since 1988, compared to the 1930s. However, this is largely explained by a higher sampling effort in the second period and some unexplained omissions in Wohlenberg's records, except for the nine species of exotic origin. These have immigrated after the 1930s and constitute an 
Fig. 7 Occurrence of mussels Mytilus edulis (small dots) and wrack Fucus vesiculosus forma mytili (large filled circle) in the lower tidal zone from 1988 to 2006 (Gröning-Watt, Königshafen Sylt)
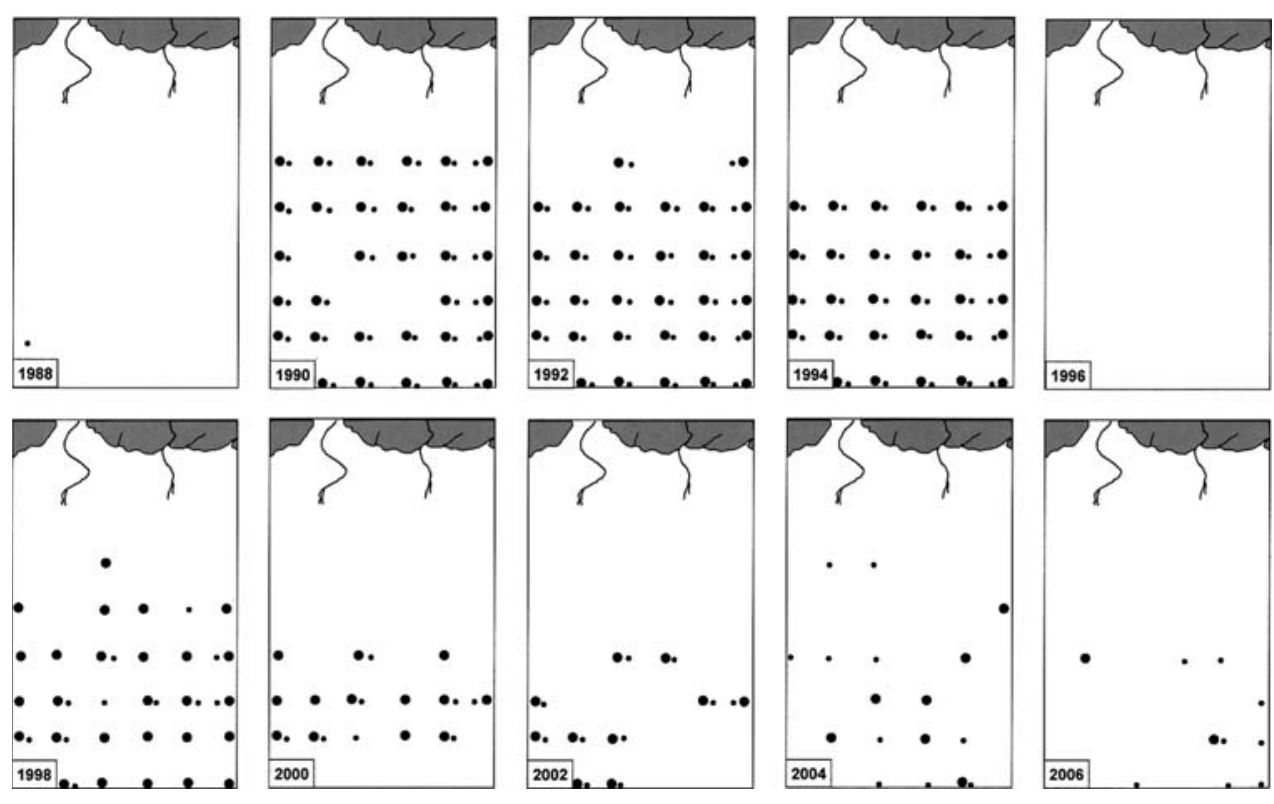

addition because no losses in other species can be attributed to their presence (see Reise et al. 1999, 2006).

Biotic zonation, known to be a highly persistent phenomenon on rocky shores (Lewis 1964; Paine 1994), is generally also present at sediment shores but less conspicuous and more variable (e.g., Eltringham 1971; Reise 1985; Peterson 1991). At the study site, a relatively clear-zoned pattern recorded in the 1920s and 1930s (Nienburg 1927; Wohlenberg 1937), has more or less dissolved into a variable patchiness (Table 1).

Only the saltmarsh seems to have persisted without notable change. This habitat was apparently capable of adapting its elevation to a rise in high water levels. At other sites in Königshafen, saltmarshes show a cliffed erosional edge, which is retreating. Apparently, such a development is prevented at the study site by the sandy berm, which has arisen in front of the saltmarsh. This, however, partly buried the former belt with a biofilm of cyanobacteria, covering clayey sediment and which does grow on the sand.

A decline of the C. volutator population in Königshafen already commenced in 1975 (Reise 1978). There, this amphipod had disappeared entirely in the 1980s (Reise et al. 1989) and has not come back, but it is still present regionally. C. volutator has been shown to be affected by trematodes (Jensen and Mouritsen 1992) or by a coverage of green algal mats (Raffaelli et al. 1991). However, both effects are unlikely to explain a complete loss of the amphipod population in Königshafen. At the study site, erosion and a concomitant advance of sandiness at the upper tidal zone may have altered the habitat unsuitable to the mudshrimp, and the frequent cover with mats of Enteromorpha spp. could have been the final blow to the population.

The advancing sandiness at the site presumably has facilitated the spread of lugworms relative to their rather restricted occurrence in the 1930s (Figs. 1, 3). Dense lugworm populations are known to have negative effects on Z. noltii (Philippart 1994), on C. volutator (Flach 1992; Flach and Bruin 1994), and on $N$. diversicolor (Zipperle and Reise 2005; Volkenborn and Reise 2006), and may facilitate the development of Enteromorpha-mats by anchoring algal strings in the sediment (Reise 1983). The bioturbating activity of A. marina has been shown to maintain sediment permeability and sandiness (Volkenborn et al. 2007). To reveal interactions between lugworms and ragworms, particularly effects of the invasion of $N$. virens, our mapping approach was presumably not detailed enough with respect to size-classes and abundance.

Seagrass never became as widespread again as described by Nienburg (1927) for Königshafen, and the area covered varied over the decades (Wohlenberg 1935; Reise et al.
Table 1 From distinct belts to patch dynamics between the tide marks in inner Königshafen, Sylt

\begin{tabular}{lll}
\hline 1920-1930s & Zone & 1990-2000s \\
\hline Puccinellia-saltmarsh & 1 & Puccinellia-saltmarsh \\
Cyanobacterial-belt & 2 & Cyano-patches and sandy beach \\
Corphium-belt & 3 & Lugworms, green algal mats, and seagrass \\
Seagrass-belt & 4 & Green algal mats, lugworms, and seagrass \\
Mussels-fucoids, Corophium & 5 & Mussels-fucoids, green algal mats, and seagrass \\
\hline
\end{tabular}


1989; Reise and Kohlus 2007). At the study site, the dissolution of the $Z$. noltii-belt can be attributed to the recurrent cover of green algal mats, while Z. marina is apparently capable of coexisting with green algal mats, at least to some extent.

Massive green algal mats first appeared in Königshafen in 1979, and since the 1980s became a regular phenomenon (Reise et al. 1989). The same happened elsewhere in the Wadden Sea (Reise and Siebert 1994; Kolbe et al. 1995; van Beusekom et al. 2005) as well as at other developed coasts (Fletcher 1996). Excessive growth of green algae in coastal lagoons and estuaries has been attributed to high nutrient supply, reactive nitrogen in particular (Morand and Merceron 2005). The consequences are mostly adverse to other benthos (Raffaelli et al. 1998), including seagrass (den Hartog 1994; Cardoso et al. 2004), although birds may take some intermittent benefit by foraging on infauna escaping from arising anoxia underneath the mats (Metzmacher and Reise 1994).

At the study site, the variable occurrence of green algal mats may be a major cause for shifting patterns and patchiness in infauna and seagrass (e.g., Figs. 2, 3, 6), and mass mortalities in cockles below green algal mats have been particularly observed in late summer of 2001 and 2006. We regard green algal mats as the most pivotal biotic change at the site, affecting almost all other benthic components.

The variable occurrence of mussels with attached $F$. vesiculosus forma mytili, however, may not be related to green algae but is apparently driven by anomalous events. In the 1920s, Nienburg (1927) blamed an unusually strong storm surge for dislocating the wrack. Wohlenberg (1937) observed a decline between 1932 and 1934 at a time when there were no green algal mats around. Nehls and Thiel (1993) stressed the effects of storm surges while Strasser et al. (2001) stressed the effects of ice floes in the severe winter of 1995/1996 on losses of mussel beds in the northern Wadden Sea. The lack of recovery at the study site since that winter is not clear, and may be attributed to limited supply of mussel recruits. There has been a general lack of mussel recruitment in the Sylt region for reasons that are not well understood (Nehls et al. 2006). As already shown by Nienburg (1927) and re-investigated by Albrecht (1998), M. edulis is essential for the occurrence of $F$. vesiculosus forma mytili on tidal flats in Königshafen by anchoring thalli with byssal threads. Nevertheless, drifting thalli without mussels or only dead mussels were often found at the study site.

\section{Conclusions and perspectives}

The pair of years in the 1930s and the 10 years between 1988 and 2006 consistently differ (1) in a Corophium popu- lation and a coherent belt of seagrass dominated by Z. noltii present in the 1930s only, (2) in the presence of a sandy berm fringing the saltmarsh edge and green algal mats covering often most of a former Corophium- and seagrass-belt in the decades after the 1930s as well as (3) in the immigration of nine species of exotic origin while only one species (C. volutator) has gone since the 1930s. We conclude these changes are not merely interannual fluctuations but represent a transition into a new ecological state. Overall, the distinctly zoned pattern of the 1930s gave way to a dynamic patchwork of low predictability with no inclination to reverse back to the structure of the 1930s (Fig. 8).

These striking changes in the biota of a tidal flat in the course of 7 decades are attributed to a combination of four processes: (1) introduced species of exotic origin have added to local species richness, (2) extreme weather events initiated the loss of mussels with attached fucoid algae, (3) eutrophication gave rise to massive green algal mats which affected most infauna and seagrass, and initiated high patch dynamics, (4) sea level rise, particularly high tidal and storm surge levels, is most likely responsible for sand accretion smothering the cyanobacterial mats at the saltmarsh edge, and for sandiness at the expense of mud in the tidal zone, inhibiting $C$. volutator and facilitating $A$. marina.

We do not regard this potpourri of changes as a regime shift where multiple variables are driven from one stable phase to another by some large-scale climatic or hydrodynamic process, as statistically identified by Weijerman et al. (2005) for the North Sea around 1979 and 1988. In our case study, independent causes of change interactively produced the current biotic pattern. This contingent outcome cannot be expected to return to a previous state even if nutrient loads continue to decrease or many years have elapsed after a weather anomaly. Any historical reference is no more than a disconcerting ghost of the past, a delusive light, not likely to be approached again even if human impacts cease altogether.

Instead, we may expect more species of exotic origin to establish at the study site, particularly those that are already present in the region. The cordgrass $S$. anglica, occurring with a large tussock at the landward boundary, almost certainly will expand further and colonize the edge of the saltmarsh and the uppermost tidal zone, replacing the remaining cyanobacterial mats. Loebl et al. (2006) suggest that warmer spring temperatures may have facilitated the spread of this invasive species at the northern edge of its present range in recent years.

It is still a matter of debate how fast sea levels will rise (Rahmstorf 2007); however, no scenario of climate change predicts sea level to fall again (IPCC 2007). Thus, sand accretion in front of the saltmarsh is expected to continue and the transformation of the muddy flat into a sandy flat to 
Fig. 8 Macrobenthic zonation in Gröning-Watt (Königshafen Sylt) from a Puccinellia-saltmarsh down to low tide level in 1932 (schematic after Wohlenberg 1937; see Fig. 1) and 7 decades later following a rise in high water level and eutrophication (see text). 1 saltmarsh, 2 Cyanobacteria-mats, 3 Corophium volutator-belt, 4 Arenicola marina, 5 Zostera noltii, $6 \mathrm{Z}$. marina, 7 Fucus vesiculosus forma mytili anchored by mussels Mytilus edulis, 8 sandy beach, 9 filiform green algal mats of Enteromorpha spp., 10 Chaetomorpha sutoria-mats, 11 lettuce-like green algal mats of Ulva spp
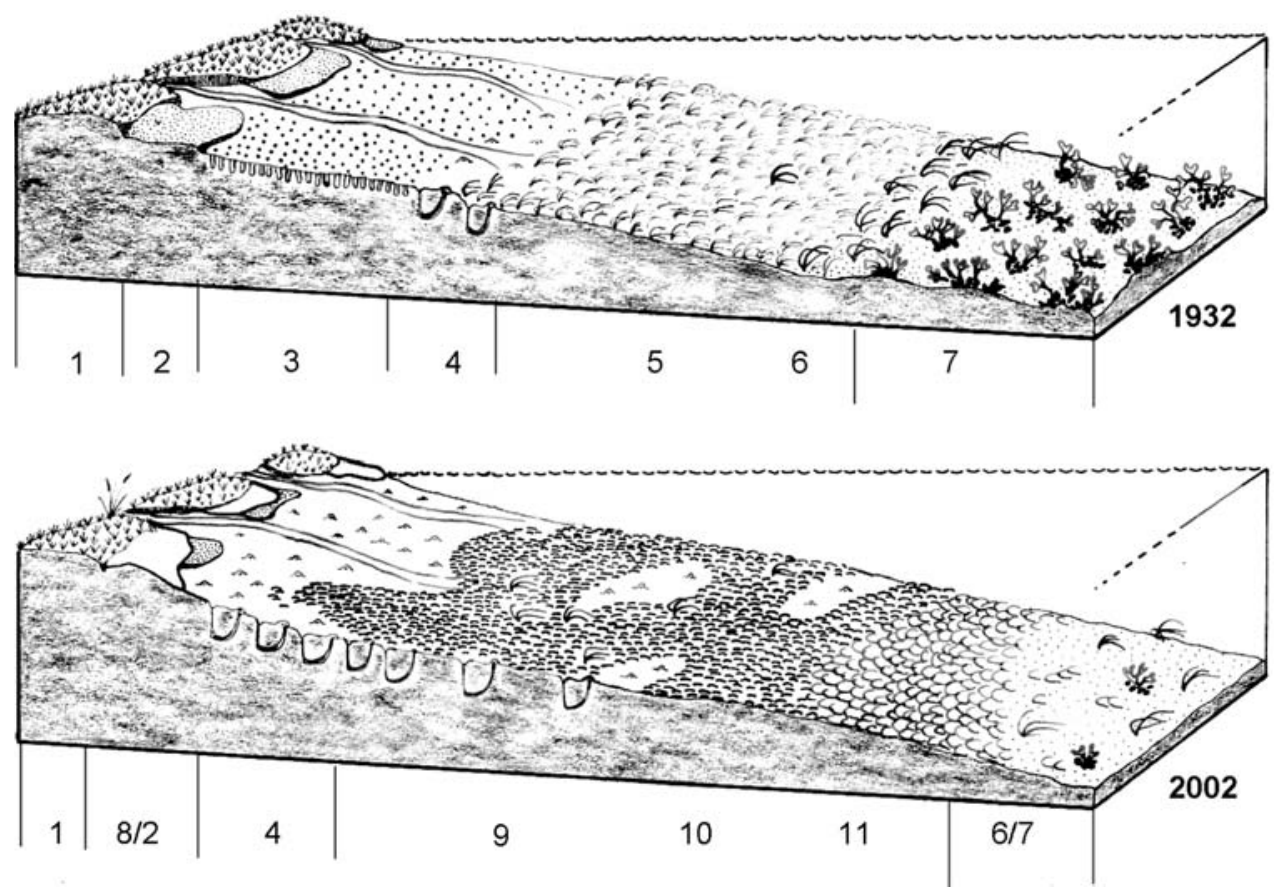

proceed. No cues are available on future changes in the lower tidal zone. While the most pivotal change of the past decades, the "green tide" of macroalgae, has been linked to eutrophication, future changes are more likely to be caused by a combination of warming, sea level rise, and invasions of alien species. Any longing for a reversal will be in vain.

Acknowledgments Thanks are due to an anonymous reviewer for helpful comments and to Tobias Dolch for advice in geographical positioning. We acknowledge the support by the MARBEF Network of Excellence "Marine Biodiversity Functioning" which is funded in the Community's Sixth Framework Programme (contract no. GOCE-CT2003-505446).

\section{References}

Airoldi L, Beck MW (2007) Loss, status, and trends for coastal marine habitats of Europe. Oceanogr Mar Biol Ann Rev 45 (in press)

Albrecht AS (1998) Soft bottom versus hard rock: community ecology of macroalgae in intertidal mussel beds in the Wadden Sea. J Exp Mar Biol Ecol 229:85-109

Austen I (1992) Geologisch-sedimentologische Kartierung des Königshafens (List/Sylt). Meyniana 44:45-52

Austen I (1994) The surficial sediments of Königshafen — variations over the past 50 years. Helgoländer wiss Meeresunters 48:163-171

Bayerl KA, Hilgelke B (1994) The development of northern Sylt during the latest Holocene. Helgoländer wiss Meeresunters 48:145162

Beusekom JEE van (2005) A historic perspective on Wadden Sea eutrophication. Helgol Mar Res 59:45-54

Beusekom JEE van, Bot P, Göbel J, Hanslik M, Lenhart HJ, Pätsch J, Peperzak L, Petenati T, Reise K (2005) Eutrophication. In: Essink $\mathrm{K}$, et al (eds) Wadden Sea quality status report 2004. Common Wadden Sea Secretariat, Wilhelmshaven, Germany, Wadden Sea Ecosystem 19:141-154
Cardoso PG, Pardal MA, Lillebø AI, Ferreira SM, Raffaelli D, Marques JC (2004) Dynamic changes in seagrass assemblages under eutrophication and implications for recovery. J Exp Mar Biol Ecol 302:233-248

den Hartog C (1994) Suffocation of a littoral Zostera bed by Enteromorpha radiata. Aquat Bot 47:21-28

Diederich S, Nehls G, Beusekom JEE van, Reise K (2005) Introduced Pacific oysters (Crassostrea gigas) in the northern Wadden Sea: invasion accelerated by warm summers? Helgol Mar Res 59:97106

Eltringham SK (1971) Life in mud and sand. English University Press, London, p 218

Flach EC (1992) The influence of four macrobenthic species on the abundance of the amphipod Corophium volutator on tidal flats of the Wadden Sea. Neth J Sea Res 29:379-394

Flach EC, Bruin W (1994) The activity of cockles, Cerastoderma edule (L.), and lugworms, Arenicola marina (L.), make Corophium volutator (Pallas) more vulnerable to epibenthic predators: a case of interaction modification. J Exp Mar Biol Ecol 182:265285

Fletcher RL (1996) The occurrence of "green tides": a review. In: Schramm/Nienhuis (eds) Marine benthic vegetation. Ecological Studies. Springer, Heidelberg, pp 7-43

Hare SR, Mantua NJ (2000) Empirical evidence for North Pacific regime-shifts in 1977 and 1989. Prog Oceanogr 47:103-145

Higelke B (1998) Morphodynamik des Lister Tidebeckens (with English abstract). In: Gätje C, Reise K (eds) Ökosystem Wattenmeer: Austausch-, Transport- und Stoffumwandlungsprozesse. Springer, Heidelberg, pp 103-126

IPCC (2007) Climate change 2007: the physical science basis. International Panel on Climate Change, http://www.ipcc.ch

Jensen KT, Mouritsen KN (1992) Mass mortality in two common softbottom invertebrates, Hydrobia ulvae and Corophium volutator-the possible role of trematodes. Helgoländer wiss Meeresunters 46:329-339

Jensen J, Mügge H-E, Schönfeld W (1992) Analyse der Wasserstandsentwicklung und Tidedynamik in der Deutschen Bucht. Die Küste 53:211-275 
Kolumbe E (1932) Ein Beitrag zur Kenntnis der Entwicklungsgeschichte des Königshafens bei List auf Sylt. Wiss Meeresunters Kiel 21:116-130

Kolbe K, Kaminski E, Michaelis H, Obert B, Rahmel J (1995) Macroalgal mass development in the Wadden Sea: first experiences with a monitoring system. Helgoländer wiss Meeresunters 49:519-528

Kornmann P (1952) Die Algenvegetation von List auf Sylt. Helgoländer wiss Meeresunters 4:55-61

Kröncke I (1992) Macrofauna standing stock of the Dogger bank. A comparison: III. 1950-54 versus 1985-87. A final summary. Helgoländer wiss Meeresunters 46:137-169

Lewis JR (1964) The ecology of rocky shores. English University Press, London, p 323

Loebl M, Beusekom JEE van, Reise K (2006) Is spread of the neophyte Spartina anglica recently enhanced by increasing temperatures? Aquat Ecol 40:315-324

Lotze HK (2005) Radical changes in the Wadden Sea fauna and flora over the last 2,000 years. Helgol Mar Res 59:71-83

Metzmacher K, Reise K (1994) Experimental effects of tidal flats epistructures on foraging birds in the Wadden Sea. Ophelia Suppl $6: 217-224$

Meyn L (1876) Geognostische Beschreibung der Insel Sylt und ihrer Umgebung. Abh geol SpezKarte Preußen thüring Staaten 1(4):1155

Morand P, Merceron M (2005) Macroalgal population and sustainability. J Coast Res 21:1009-1020

Nehls G, Diederich S, Thieltges DW, Strasser M (2006) Wadden Sea mussel beds invaded by oysters and slipper limpets: competition or climate control? Helgol Mar Res 60:135-143

Nehls G, Thiel M (1993) Large-scale distribution patterns of the mussel Mytilus edulis in the Wadden Sea of Schleswig-Holstein: do storms structure the ecosystem? Neth J Sea Res 31:181-187

Nes EH van, Amaro T, Scheffer M, Duineveld GCA (2007) Possible mechanisms for a marine benthic regime shift in the North Sea. Mar Ecol Prog Ser 330:39-47

Nienburg W (1927) Zur Ökologie der Flora des Wattenmeeres. I. Der Königshafen bei List auf Sylt. Wiss Meeresunters Kiel 20:146196

Newig J (1980) Zur Entwicklung des Listlandes auf Sylt in den letzten drei Jahrhunderten-ein historisch-kartographischer Vergleich. Nordfries Jb 16:69-74

Paine RT (1994) Marine rocky shores and community ecology: an experimentalist's perspective. Ecology Institute, Oldendorf/Luhe, Germany, p 159

Pearson TH, Josefson AB, Rosenberg R (1985) Petersen's stations revisited. I. Is the Katttegat becoming eutrophic? J Exp Mar Biol Ecol 92:157-206

Pejrup M, Larsen M, Edelvang K (1997) A fine-grained sediment budget for the Sylt-Rømø tidal basin. Helgoländer wiss Meeresunters $51: 253-268$

Peterson CH (1991) Intertidal zonation of marine invertebrates in sand and mud. Am Sci 79:236-249

Philippart CJM (1994) Interactions between Arenicola marina and Zostera noltii on a tidal flat in the Wadden Sea. Mar Ecol Prog Ser 111:251-257

Priesmeier K (1970) Form und Genese der Dünen des Listlandes auf Sylt. Schr naturwiss Ver Schleswig-Holstein 40:11-51

Raffaelli D, Limia J, Hull S, Pont S (1991) Interactions between the amphipod Corophium volutator and macroalgal mats on estuarine mudflats. J Mar Biol Assoc UK 71:899-908

Raffaelli DG, Raven JA, Poole LJ (1998) Ecological impacts of green macroalgal blooms. Oceanogr Mar Biol Ann Rev 36:97-125

Rahmstorf S (2007) A semi-empirical approach to projecting future seal-level rise. Science 315:368-370
Rasmussen E (1973) Systematics and ecology of the Isefjord marine fauna (Denmark). Ophelia 11:1-495

Reise K (1978) Experiments on epibenthic predation in the Wadden Sea. Helgoländer wiss Meeresunters 31:55-101

Reise K (1983) Sewage, green algal mats anchored by lugworms, and the effects on Turbellaria and small Polychaeta. Helgoländer wiss Meeresunters 36:151-162

Reise K (1985) Tidal flat ecology. Ecological studies 54. Springer, Heidelberg, 191p

Reise K (2005) Coast of change: habitat loss and transformations in the Wadden Sea. Helgol Mar Res 59:9-21

Reise K, Kohlus J (2007) Seagrass recovery in the northern Wadden Sea? Helgol Mar Res (this volume)

Reise K, Siebert I (1994) Mass occurrence of green algae in the German Wadden Sea. Dt Hydrogr Z Suppl 1:171-180

Reise K, Herre E, Sturm M (1989) Historical changes in the benthos of the Wadden Sea around the island of Sylt in the North Sea. Helgoländer wiss Meeresunters 43:417-433

Reise K, Herre E, Sturm M (1994) Biomass and abundance of macrofauna in intertidal sediments of Königshafen in the northern Wadden Sea. Helgoländer wiss Meeresunters 48:201-215

Reise K, Gollasch S, Wolff WJ (1999) Introduced marine species of the North Sea coasts. Helgoländer wiss Meeresunters 52:219-234

Reise K, Olenin S, Thieltges DW (2006) Are aliens threatening European aquatic coastal ecosystems? Helgol Mar Res 60:77-83

Rosenberg R, Gray JS, Josefson AB, Pearson TH (1987) Petersen's benthic stations revisited. II. Is the Oslofjord and eastern Skagerrak enriched? J Exp Mar Biol Ecol 105:219-251

Schories D, Albrecht A, Lotze HK (1997) Historical changes and inventory of macroalgae from Königshafen Bay in the northern Wadden Sea. Helgoländer wiss Meeresunters 51:321-341

Strasser M, Reinwald T, Reise K (2001) Differential effects of the severe winter of 1995/96 on the intertidal bivalves Mytilus edulis, Cerastoderma edule and Mya arenaria in the Northern Wadden Sea. Helgol Mar Res 55:190-197

Ten Brink BJE, Hosper SH, Colijn F (1991) A quantitative method for the description and assessment of ecosystems: the AMOEBA approach. Mar Pollut Bull 23:265-270

Volkenborn N, Reise K (2006) Lugworm exclusion experiment: responses by deposit feeding worms to biogenic habitat transformations. J Exp Mar Biol Ecol 330:169-179

Volkenborn N, Hedtkamp S, Beusekom JEE van, Reise K (2007) Effects of bioturbation and bioirrigation by lugworms (Arenicola marina) on physical and chemical sediment properties and implications for intertidal habitat succession. Estuar Coast Shelf Sci (in press)

Weijerman M, Lindeboom H, Zuur AF (2005) Regime shifts in marine ecosystems of the North Sea and Wadden Sea. Mar Ecol Prog Ser 298:21-39

Weisse R, Plüß A (2006) Storm-related sea level variations along the North Sea coast as simulated by a high-resolution model 1958 2002. Ocean Dyn 56:16-25

Wohlenberg E (1935) Beobachtungen über das Seegras Zostera mari$n a$ L. und seine Erkrankung im nordfriesischen Wattenmeer. Nordelbingen 11:1-19

Wohlenberg E (1937) Die Wattenmeer-Lebensgemeinschaften im Königshafen von Sylt. Helgoländer wiss Meeresunters 1:1-92

Wolff WJ (2005) Non-indigenous marine and estuarine species in The Netherlands. Zoologische Mededelingen 79:1-116

Zipperle A, Reise K (2005) Freshwater springs on intertidal sand flats cause a switch in dominance among polychaete worms. J Sea Res $54: 143-150$ 